\title{
Capital Movements and Economic Growth Fluctuations: The Threshold Effect of Financial Development
}

\author{
Noureddine Khadraoui \\ Faculty of Economic Sciences and Management \\ University of Sousse, 4023, Tunisia \\ Research Unit: MO2FID \\ Tel: 216-98-447-519Ｅ-mail: kadnour@yahoo.fr
}

Received: December 26, 2011

doi:10.5539/ijef.v4n4p193

\author{
Accepted: January 29, 2012 \\ Published: April 1, 2012 \\ URL: http://dx.doi.org/10.5539/ijef.v4n4p193
}

\begin{abstract}
We examine the relationship between capital account openness and growth volatility according to the level of financial development condition. We demonstrate that economies with high level of financial sector development benefit more from capital flows than those with a lower one. In what follows, we extend previous studies by employing updated data, and also exploring more questions related to the links between capital movements and growth volatility. More specifically, we will investigate the issues relevant to threshold effect of financial development on which capital flows changes of sign. We investigate the role of financial development in the relationship between capital flows and growth volatility for different groups of countries. Estimations are conducted with a panel data of 70 countries over the period 1970-2009 using GMM-System estimator for dynamic panel data. Empirical results support that capital movements aggravate macroeconomic volatility according to the level of domestic financial development. This implies that countries which are at an intermediate phase of financial development are the most vulnerable to instability. This threshold is estimated at a rate of credits to the private sector to GDP around $50 \%$.
\end{abstract}

Keywords: Financial development, Financial integration, Capital movements, Macroeconomic volatility

\section{Introduction}

Given their low level of capital and their biggest volatility, developing countries, particularly seem to have most interest to benefit from the process of financial integration. Since the decision-makers estimate the risks and the advantages of capital flows including its implications for growth, the volatility took a big importance. Therefore, there was a debate on the impact of capital flows on economic growth. In spite of the crises which shook emerging countries, certain works have shown that the advantages of the capital flows are acquired on the long run. Several other studies have examined the causal relation between financial integration and economic growth. Although many of these studies concluded that capital flows really produces advantages for growth. Hence, this relation is not yet found to be strong. In this context, we address the question to whether really financial development threshold enables capital flows reduce macroeconomic volatility.

The remainder of this paper is organized as follows. The next section provides a brief theoretical and empirical review on the relationship between financial development, capital flows and macroeconomic volatility. Section 3 highlights an econometric analysis where descriptive statistics, model and estimated methodology are described. Empirical results and discussions are presented in Section 4. Finally, this piece of research concludes with Section 5.

\section{The Review of the Literature}

The international capital flows has considerably increased since the end of 1980 s and it has been a source of important potential advantages. At first, opening to international capital markets supplies additional resources to finance investment. It also can lead to a bigger capital accumulation. This is particularly in the countries where the capacity of savings is forced by a low level of income. Besides, financial integration can lead to a more efficient allocation of capital by improving the discipline of market and by strengthening banking system. The greater allocation of capital and efficiency has the objective to decrease the investment costs and to spur economic growth. Another major source of advantages is to facilitate the sharing of international risk by supplying more opportunities for the diversification of portfolios. This channel supplies additional means of insurance for companies by allowing 
them to invest in projects with high return and more risks. However, if these potential advantages are theoretically well established, the empirical evidence still mitigate and rather weak.

Most of the theoretical studies on the capital flows have been concentrated on the evaluation of the impact of capital account opening on growth rate, (Edison and al., 2002). The attention has been shifted the relation between financial openness and macroeconomic volatility. After financial crises of the 1980s and 1990 which followed reforms of liberalization of the major account, some studies supported that capital flows could be a source of bigger macroeconomic volatility. This is going to expose the countries to be vulnerable in the sudden reversals of capital flows, (Kaminsky and Reinhart, 1999). According to this line of explanation, some countries are going to run a higher macroeconomic volatility by what they miss in terms of political instruments to smooth the cycles. Particularly, they miss adequate financial institutions to avoid sudden reversals of capital flows. Even, without considering external episodes of macroeconomic volatility (as the financial crisis), financial integration associated with weakness of domestic financial institutions could strengthen existing changes due to imperfections of credit market. This can also bring report of volatility of the cycles of the economic activity. In the presence of information asymmetries, opening of capital account supplies additional liquidity to domestic banking system and leverage more raised for the loans of firms. In this context, capital flows can amplify the mechanism of financial accelerator identified in the study of Bernanke and al. (2000). International financial integration can have two major potential advantages: the improvement of global allocation of capital and the assistance of countries to better share risk by reducing consumption volatility, (Mr. Ayhan Kose, Eswar Prasad and Marco Terrones; 2003). The understanding of the dynamics of macroeconomic volatility is recently moved for certain reasons. At first, suggestions of Ramey and Ramey; (1995) showed the existence of a negative relation between growth and its volatility. As quoted previously, the literature handled only the theoretical links and the channels of influence between financial development and economic growth. This interconnection always appreciated the positive impact of development of the financial sector on growth. The potential connections between financial development and growth volatility were not completely studied. However, the increase of growth volatility of that many developing countries have experienced in the last decades, brought an important and recurrent question: at which level can production fluctuations be moved closer to financial development sector?

The previous studies of Easterly and al. (2000), Denizer and al. (2002), Haussmann and Gavin (1996); and Raddatz (2006) showed that financial development reduces macroeconomic volatility. The conclusion from these suggestions is that none tried to identify channels by which financial development affects potentially growth volatility. In an attempt to examine if financial intermediaries serve either as shock absorbers by easing the effect of the real or monetary volatility on that of the economic growth, or as an amplificator. On the one hand, this ensues from works of Bernanke and Gertler (1989) which showed that if the net value of borrowers is affected by a shock, this is going to amplify volatility of economy through the effect of investment accelerator. In this direction, Acemoglu and Zilibotti (1997) suggested that the interaction between indivisibility of investment and incapacity of risk diversification increases economic volatility. On the other hand, and in the same current of the literature, the studies of Bernanke and Blider (1992) and Bernanke and Gertler (1995) proposed that monetary policy can affect real economy through its effect on credit market. By reference to the model of Bacchetta and Caminal (2000), some studies showed that the entrepreneurs, by difference in their levels of wealth, have access to financial markets. The emergence of financial intermediaries is due to information asymmetries between lenders and borrowers, (Thorsten Beck, Mattias Lundberg and Giovanni; (2006)). Unlike Bacchetta and Caminal, these works explicitly modelled financial intermediation making use of the channel of monetary policy. They studied two types of shocks: the real shocks which affect only the non financial institutions and the monetary shocks which affect only the banking balance sheets. Because entrepreneurs produce at different levels of productivity by depending on the internal resources level, real and monetary shocks will have distributional effects resulting from its impact on the output. Although depends on the nature of shock that is cooled or amplified. We can note that theoretical studies examining financial integration effects on business cycles volatility failed to bring conclusive results.

Empirically, by using a dynamic stochastic model, Mendoza (1994) discovered that there are low production and consumption volatilities simultaneously with a greater financial integration. In front of bigger and more persistent shocks, there is a proof which production volatility increases with degree of financial integration. Unlike, Baxter and Grucini (1995) showed that there is a negative relation between capital flows and both relative and absolute consumption volatility. For them, production volatility is found to increase with a bigger financial integration. The changes observed by production and consumption volatility are largely awarded to wealth effects and their interaction with risk sharing. This depends on the various structures of market assets. The analysis of capital flows impact on macroeconomic volatility can be complicated by other factors. 
Another branch of studies showed that the degree of influence on output and consumption volatility depends on the nature of shocks affecting economy. In case of monetary and fiscal shocks, volatilities of production and consumption move simultaneously with increase of financial integration, (Sutherland; (1996), Senay; (1998) and Buch, Doepke and Pierdzioch; (2005)). Rodrik (1998) supported that with financial integration, opened economies have a wider exhibition shocks in the world market and their structures. This underlies the degree of exports and the diversification of imports which determine their capacity to absorb terms of trade and foreign demand shocks. These shocks explain a significant fraction of the volatility in developing countries. Aghion and al. (1999) and Aghion and al. (2000) argued that countries with a low level of financial development can expose more volatile growth rates. However, Beck and al. (2001) concluded that it's not the case that financial development effect on volatility depends on the nature of shocks which affect economy whether real or monetary. By using a panel of 63 countries over the period 1960-1997, no strong relation was found between financial development and growth volatility. Other recent works focused on interdependence between domestic and foreign financial markets. Chang and Valesco (1999) have examined the influence of banks and foreign investors on domestic banking systems. Caballero and Krishnamurthy (2001) have investigated the role of domestic financial system in the access to international financial markets. Razin and Rose (1994) have investigated the impact of trade openness on the volatilities of production, consumption and investment for a sample of 138 countries over the period 1950-1988. They found an insignificant relation between openness and macroeconomic volatility. Estearly, Islam and Stiglitz (2001) have looked for sources of volatility by using a sample of 74 countries over the period 1960-1997. Therefore, they found that countries having a more developed domestic financial sector are associated to a lower volatility. In spite of the richness empirical literature which studied the impact of financial openness on economic growth, the studies of links between openness and macroeconomic volatility are limited.

\section{An Econometric Analysis of Financial Integration, Growth Volatility and Financial Development}

\subsection{Data and Sample}

The used sample consists of 70 developed and developing countries. The period of study extends over 1970-2009 where the observations for each country is averaged on 5 years periods (Note 1). Data are used from WDI database (2009), IFS database (2009) and database built by Levine (2009). The indicator of financial development is measured by ratio of credits to the private sector to GDP. The net private capital flows to the GDP is a de facto measure of financial integration. Here we use that in Lane and Milesi-Ferretti (2006). For growth volatility we shall use the standard deviation of GDP in Log for every five years period. The same procedure is adopted for other variables of control: the inflation rate volatility which is measured by standard deviation of Log (1+inflation), the standard deviation of trade openness $((\mathrm{X}+\mathrm{M}) / \mathrm{GDP})$; exchange rate stability used in Aizenman (2008) and standard deviation of government spending (G/GDP).

\subsection{The Descriptive Statistics}

According to the results presented in table 1 we notice that growth volatility marked the most raised value during the decades of $80 \mathrm{~s}$ and $90 \mathrm{~s}$ for emerging countries (MFI). This period was qualified by adoption of certain policies such as financial liberalization and integration. Consequently, these countries witnessed economic recessions due to crises arisen from this period. Unlike developing countries, volatility was almost stable in developed countries during the four decades. However, in less financially integrated countries, volatility is showed in decline throughout studied period.

Table 2 shows that financial development indicator reaches the maximum values in developed countries and is gradually growing through decades. The more developed financial systems are the most active and efficient ones in allocation of resources. In other cases, we notice that financial development indicator whose tendency seems to be stable for the most opened countries. (Note 2)

\subsection{The GMM-System in Dynamic Panel Data}

The methodology of Generalized Method of Moments (GMM) for panel data analyses, proposed by Arellano and Bond (1991) and then further developed by Blundell and Bond (1998), is employed here to control for endogeneity in our estimations. The data will be calculated every 5 year period from 1970 to 2009. It gives a balanced panel of 70 countries and 8 periods. The empirical results suggest, however, that the past volatility is suited in the explanation of the current volatility for the economic growth. The following presentation of the structure of the model of regression is based on a dynamic specification. We are going to consider the model of following regression:

$$
\mathrm{y}_{\mathrm{i}, \mathrm{t}}=\alpha \mathrm{y}_{\mathrm{t}-1}+\beta \mathrm{x}_{\mathrm{i}, \mathrm{t}}+\mu_{\mathrm{i}}+\epsilon_{\mathrm{i}, \mathrm{t}}
$$


With $\mu_{\mathrm{i}}$ and $\epsilon_{\mathrm{i}, \mathrm{t}}$ are independently distributed, $\mathrm{E}\left[\mu_{\mathrm{i}}\right]=\mathrm{E}\left[\epsilon_{\mathrm{i}, \mathrm{t}}\right]=\mathrm{E}\left[\mu_{\mathrm{i}} \epsilon_{\mathrm{i}, \mathrm{t}}\right]=0$ for $\mathrm{i}=1, \ldots, \mathrm{N}$ and $\mathrm{t}=2, \ldots, \mathrm{T}$ and $\mathrm{E}\left[\epsilon_{\mathrm{i}, \mathrm{t}} \epsilon_{\mathrm{i}, \mathrm{s}}\right]=0 \quad \forall \mathrm{t} \neq \mathrm{s}$. With this specification and our structure of panel (raised $\mathrm{N}$ and short $\mathrm{T}$ ), the OLS estimator is biased. Arellano and Bond (1991) and Arellano and Bover (1995) proposed the linear GMM-IV estimator which consists in taking for each equation the first difference of the equation to be estimated in order to eliminate the specific effects of countries; and then use the values in a lagged level with one period at most from the explanatory variables as instruments of these variables at the level of the equation in first difference. The System-GMM estimator developed by Arellano and Bover (1995) consists in estimating a system of equations (one for each time period) specified in level and in first difference. The consistency of the GMM estimator depends on the validity of the assumption that the error terms do not exhibit serial correlation and on the validity of the instruments. To address these issues, we use two specification tests suggested by Arellano and Bond (1991), Arellano and Bover (1995), and Blundell and Bond (1998). The first is a Sargan test of over-identifying restrictions, which tests the overall validity of the instruments by analyzing the sample analog of the moment conditions used in the estimation process. The second test examines the hypothesis that the error term $\epsilon_{\mathrm{i}, \mathrm{t}}$ is not serially correlated. We test whether the differenced error term is second-order serially correlated (by construction, the differenced error term is probably first-order serially correlated even if the original error term is not). Failure to reject the null hypotheses of both tests gives support to our model.

\subsection{Model and Estimation Strategy}

Referring to previous modeling, we consider following both dynamic equations where we introduce the financial development and financial integration:

$$
\begin{gathered}
y_{i, t}=\alpha y_{i, t-1}+\beta_{1} x_{i, t}+\beta_{2} D F_{i, t}+\beta_{3} F_{i, t}+\mu_{i}+\epsilon_{i, t} \\
y_{i, t}=\alpha y_{i, t-1}+\beta_{1} x_{i, t}+\beta_{2} D F_{i, t}+\beta_{3} F_{i, t}+\beta_{4}\left(D_{i, t} \cdot F_{i, t}\right)+\mu_{i}+\epsilon_{i, t}
\end{gathered}
$$

Where, $y_{i t}$ is the growth volatility for country $i$ in year $t$. More specifically, $y_{i t}$ is either output volatility measured as the five-year standard deviations of GDP per capita; (DF) is the private credit as a ratio to GDP as a measure of financial development; (FI) is a de facto measure of financial integration. Here we use those in Lane and Milessi-Ferretti (2006) and $\left(\mathrm{DF}_{\mathrm{i}, \mathrm{t}} \cdot \mathrm{FI}_{\mathrm{i}, \mathrm{t}}\right)$ which is an interaction term between the capital flows and the level of financial development. We are particularly interested in interaction term effect because we suspect that international capital flows may complement or substitute other conditions. $\mathrm{X}_{\mathrm{it}}$ is a vector of macroeconomic control variables that include the most used variables in the literature, namely, inflation volatility as the five-year standard deviations of inflation rate ; trade openness volatility defined as the five-year standard deviation of $((\mathrm{X}+\mathrm{M}) / \mathrm{GDP})$; government spending volatility; and exchange rate stability index used in Asieman (2008) as five-year averaged.

The parameters of interest are $\beta_{2}, \beta_{3}$ and $\beta_{4}$ which get potential interaction effect between capital flows and financial development indicators. This formulation allows the impact of the one of both variables to depend on the level of the other one. $\beta_{2}$ and $\beta_{3}$ of the equation (1) represent marginal impacts respectively of financial development and financial integration. In contrast, $\beta_{3}$ in (2) represents marginal impact of capital flows conditional on the level of financial development being zero and the interpretation which is similar for $\beta_{2}$ is also held. Finally, to obtain the level of threshold of financial development, we have to calculate from (2) the function: $\frac{\partial y}{\partial F I}=\beta_{3}+\beta_{4} \mathrm{DF}^{*}$ being equal to zero.

\section{Results and Discussions}

Our estimation has supplied the following results. First of all, we have to consider the mixed full sample, and then we shall proceed to separate groups of countries according to the degree of financial integration, adopted by Mr. Ayhan Kose, Eswar Prasad and Marco Terrones; (2003). The first estimation consists in considering the full sample mixed which contains 70 countries where 20 are industrialized economies. Second, we split developing countries (50) into two groups: 18 More Financially Integrated Economies (MFIE) and 32 Less Financially Integrated Economies (LFIE). The instrumental variables employed in our study are lagged values of indicators and time dummies to check time effect and which are not posted in the following tables.

Table 3 indicates two results. Firstly, second-order serial correlation test justifies the acceptation of the null hypothesis. Secondly and at the same time, Sargan test of over identification suggests that we cannot reject the validity of instruments hypothesis (prob $X^{2}>0.05$ ). It's noted that we have instrumented financial development indicator by its lagged values and time dummies variables to check the time effect. Column (1) shows results of the model without introduction of variables of interest (financial development and financial integration), obtained from GMM-System. The results show that coefficients associated with explanatory variables answer favorably the expected signs. The standard deviation of trade openness indicator exercises a negative effect on the severity of growth volatility. This result doesn't confirm the Rodrik's argument: more opened economies are more specialized 
and so running the biggest shocks of income, combined with imperfect financial markets, lead to a bigger macroeconomic volatility. On the one hand, instability of inflation, exchange rate volatility and government spending have positive impact on growth rate instability which showed strongly significant at $1 \%$. On the other hand, the coefficient of lagged dependent variable has a significant and positive sign with a scale less than one. Given that we have considered 5 year periods, it suggests that this volatility is relatively persistent. Furthermore, it also supports the dynamic specification adopted here. In column (3), we have introduced the financial development indicator measured by ratio of credits for the private sector divided by GDP and capital flows indicator measured by the ratio of net private capital flows to GDP. Financial development reduces favorably macroeconomic volatility by the fact that an increase in the indicator of credits of 1 point percentage weakens the volatility of 0.1 point percent. Capital flows aggravates significantly economic growth volatility of 0.02 point. This means that a developed financial system, by the exercise of functions as mentioned in Levine papers, minimizes the economic danger of skidding. Other control variables have the same signs as in (1) and (2). In model (4), it is interesting to point out that the addition of interactive term between capital flows and financial development indicators is to determine financial development threshold from which capital flows can change sign towards its effect on economic growth rate volatility. The estimation supplies a significant negative impact of the interactive term at a risk of $5 \%$. The capital flows reduces volatility as soon as certain threshold of financial development is reached by studied countries. This means that there is a threshold of financial development from which coefficient of capital flows changes sign. This threshold is determined by calculation of marginal impact of capital flows as table shows. This means that from a certain financial development level, capital flows has just brought its initial enthusiasm while reducing macroeconomic volatility. This threshold is approximate at a level of $58 \%$ of private credit ratio. A financial system, which is in phase of maturity, can run instabilities which may engender an escalation of volatility due to financial openness.

As reminder, this rate is taken by high levels of developed countries appearing in the sample. It is possible that separation procedure of samples will give more precise results which take into account heterogeneous specificities of studied groups. We shall divide sample into three groups according to the degree of capital flows as adopted by the economists, Kose, Mr A. E. Prasad, K. Rogoff, and S.J. Wei. This will give us 20 developed countries and 50 developing countries where 18 represent the Most Financially Integrated and 32 Least Financially Integrated Economies.

The estimation for developed countries sample shows that capital flows has no significant effect on growth volatility both in (3) and (4), (see table 4). Financial development indicator persists with a significantly negative effect which strengthens the idea that a developed financial system favors economic growth while minimizing economic instability. However, financial openness has no significant impact on macroeconomic volatility; this confirms the works of Kose and al. (2003) and of Easterly and al. (2004). The introduction of interactive term returns has no significant effect.

Other explanatory variables in table 5 resist by having the same signs as in regressions (1) and (2). In regression (4), addition of interaction term between capital flows and financial development has a significant negative impact which validates hypothesis that capital flows can change sign towards its effect on growth volatility. Capital flows appear reducing volatility at a determined financial development threshold which is reached by studied developing countries. This means that there is a threshold from which the coefficient of capital movements changes sign. This latter is determined from the marginal impact of capital flows as the table shows. This justifies that from a certain financial development level, the capital flows has just brought its initial enthusiasm while reducing the macroeconomic volatility. This threshold is approximate at a level of $50 \%$ of the private credit ratio. A financial system which is in phase of maturity can run instabilities which can engender an escalation of the volatility along with the financial opening.

For less financially integrated countries estimation, as shown in table 6 column (3), the increase in growth volatility during studied period is significantly better explained by evolution of lagged volatility, inflation rate volatility, exchange rate volatility, government spending volatility and the financial integration. The financial development has a significant effect on decline of macroeconomic volatility in LFIEs. This underscores that countries which have under developed financial systems can undergo instabilities further to the opening to international financial markets. However, evaluation of regression (4) suggests that coefficient of capital movements changes sign of impact on growth volatility. Therefore, this change depends on the level of financial development due to significance of interactive term indicator which is shown statistically significant. This evidence confirms the ideas of Beck and al. (2001). Then, we conclude that the financial development threshold in LFI countries, from which the capital flows changes sign towards growth volatility, is approximated at one level of $58 \%$. Generally, this result confirms and 
agrees with the most previous empirical and theoretical studies which plan and accord an ambiguous impact of capital flows on growth volatility to the nature of shocks striking the economy.

The estimated coefficients for the 18 more financially integrated economies (see table 7) have the expected sign (Note 3). The coefficient of lagged dependent variable has a significant and positive sign with a scale less than one. The impact of exchange volatility is positive on growth volatility. Then, trade openness volatility appear leading to more growth volatility which confirms the Rodrik's study (1998). Thus, more opened economies are more specialized and so throw the biggest shocks of income, combined with imperfect financial markets, lead to a bigger macroeconomic volatility. Similarly, this result agrees with work papers of Kose and al. (2003), and Easterly and al. (2004). However, the interaction term has no significant impact. This is due to advanced market financial development stages of these more financially integrated countries which allocates financial flows efficiently and enhances macroeconomic stability.

\section{Conclusion}

The contribution of this paper aims to show the relation between capital flows and macroeconomic volatility conditional to the development level of domestic financial systems. The interaction between domestic financial development and capital flows is a determinant which does not miss importance of the scale of the volatility brought by financial openness. However, capital flows is associated with the highest growth rate volatility if level of domestic financial development is below determined threshold. Our empirical results suggested that the level of financial development threshold, measured by the ratio of private credit to GDP, is estimated to be around $50 \%$. Departing from this level, we expect advantages and benefits of financial openness. It seems, however, that countries, which are at an intermediate phase of financial sector development, can be the most unstable. In terms of policy conclusion, it suggests that the financial domestic system has to be a prerequisite for financial integration decision. The basic implication is that economies which run an intermediate stage of financial development system are more unstable than those which are more or less developed economies. This is true in the sense that temporary shocks have big and persistent effects, as long as these countries can expose economic cycles. Thus, countries which are in a phase of development of their financial systems can be more unstable on the short-run. Similarly, full liberalization of capital account can destabilize these economies. This is explained by phases of growth with capital inflows. Conversely, when this process is followed by capital outflows a sudden fall certainly happen.

Financial integration can catalyze financial development, improve governance, and impose discipline on macroeconomic policies. But, in the absence of a basic pre-existing level of these supporting conditions, capital movements can aggravate instability. Broader range of financial markets, greater financial depth can help deal with shocks; make transmission of macroeconomic policies more efficient. Financial integration can support and catalyze other reforms, especially financial development. Unlike, other developing economies are still below threshold levels of financial and institutional development. Still, de facto fixed or tightly-managed exchange rates and inflation targeting create problems whenever surges in inflows. In addition, real exchange rate appreciations can affect poor and undeveloped economies. Overall, developing countries can manage risks during transition to thresholds, but cannot eliminate them. However, a selective approach to liberalization based on prioritization on collateral benefits must be adopted before.

\section{References}

Acemoglu, D., \& Zilibotti, F. (1997). Was Prometheus unbound by chance? Risk, diversification, and growth. Journal of Political Economy, 105(4), 709-751. http://www.jstor.org/stable/10.1086/262091

Aghion, P., Bacchetta, P., \& Banerjee A. (1999). Capital markets and the instability of open economics. In: P. R. Agenor, M. Miller, D. Vines, \& A. Weber (Eds.). The Asian financial crisis: causes, contagion, and consequences (pp. 167-190). Cambridge University Press. http://dx.doi.org/10.1017/CBO9780511559587.011

Aizenman, J., M. D. Chinn, \& H. Ito. (2008). Assessing the Emerging Global Financial architecture: Measuring the Trilemma's Configurations over Time. National Bureau of Economic Research (NBER) Working Paper Series \#14533.

Arellano, M. \& O. Bover. (1995). Another Look at the Instrumental-Variable Estimation of Error-Components Models. Journal of Econometrics. 68. 29-52. http://dx.doi.org/10.1016/0304-4076(94)01642-D

Arellano, M. \& S. Bond. (1991). Some Tests of Specification for Panel Data: Monte Carlo Evidence and an Application to Employment Equations. Review of Economic Studies. 58. 277-297. http://dx.doi.org/10.2307/2297968

Bacchetta, P., \& Caminal, R. (2000). Do capital market imperfections exacerbate output fluctuations? European Economic Review. 44 (3). 449-468. http://dx.doi.org/10.1016/S0014-2921(98)00083-X 
Bernanke, B. S., Gertler, M., \& Gilchrist, S. (1999). The financial accelerator in a quantitative business cycle framework. In J. B. Taylor \& M. Woodford (Eds.). Handbook of macroeconomics: (pp. 1341-1393).North Holland: Amsterdam (Chapter 21). http://dx.doi.org/10.1016/S1574-0048(99)10034-X

Bernanke, B.S., \& Blinder, A.S. (1992). The federal funds rate and the channels of monetary transmission. American Economic Review, 82(4). 901-921.

Bernanke, B.S., \& Gertler, M. (1989). Agency costs, net worth, and business fluctuations. American Economic Review, 79(1). 14-31.

Bernanke, B.S., \& Gertler, M. (1995). Inside the black box: the credit channel of monetary policy transmission. Journal of Economic Perspectives, 9 (4). 27-48.

Bernanke, B.S., Gertler, M., \& Gilchrist, S. (1996). The financial accelerator and the flight of quality. Review of Economics and Statistics, 78 (1). 1-15.

Bernanke, Ben, \& Mark Gertler. (1989). Agency Costs, Net Worth, and Business Fluctuations. American Economic Review, 79. 14-31. http://dx.doi.org/10.1126/science.151.3712.867-a

D. Rodrik. (1998). Who needs capital account convertibility? In S. Fisher et al. (Eds). Should the IMF Pursue Capital Account Convertibility? Essays in International Finance, number 207. Princeton University Press.

Denizer, C., Iyigun, M.F., \& Owen, A. L. (2002). Finance and macroeconomic volatility. Contributions to Macroeconomics, 2 (1). Article 7. Available: http://www.bepress.com/bejm/contributions/vol2/iss1/art7

E. Mendoza. (1994). The robustness of macroeconomic indicators of capital mobility. In L. Leiderman \& Razin (Eds). Capital Mobility: The Impact on Consumption, Investment, and Growth (pp. 83-111). Cambridge University.

Easterly, W., Islam, R., \& Stiglitz, J. (2000). Shaken and stirred: explaining growth volatility. In: Annual World Bank Conference on Development Economics 2000. 191-211.

G. Kaminsky, \& C. Reinhart. (1999). The twin crisis: The causes of banking and balance-of-payment problems. American Economic Review, 89:473-500. http://dx.doi.org/10.1257/aer.89.3.473

H. Edison, R. Levine, \& T. Slok. (2002). International capital flows and economic growth. Journal of International Money and Finance, 21:749-776. http://dx.doi.org/10.1016/S0261-5606(02)00021-9

Hausmann, R., \& Gavin, M. (1996). Securing stability and growth in a shock prone region: the policy challenge for Latin America. Inter-American Development Bank, Office of the Chief Economist. Working Paper, 315.

Kose, M. A., E. Prasad, K. Rogoff, \& S. J. Wei. (2006). Financial Globalization: A Reappraisal IMF Working Paper, WP/06/189.

Lane, Philip R., \& Gian Maria Milesi-Ferretti. (2007). The External Wealth of Nations Mark II, Journal of International Economics, 73. November. 223-250. http://dx.doi.org/10.1016/j.jinteco.2007.02.003

Lane, Philip R., \& Gian Maria Milesi-Ferretti. (2006). The External Wealth of Nations Mark II: Revised and Extended Estimates of Foreign Assets and Liabilities. IMF Working Paper.forthcoming (Washington: International Monetary Fund).

M. Baxter, \& M. Crucini. Business. (1995). Cycles and the asset structure of the foreign trade. International Economic Review, 36. 821-854. http://dx.doi.org/10.2307/2527261

R. Caballero, \& A. Krishnamurthy. (2001). International and domestic collateral constraints in a model of emerging market crises. Journal of Monetary Economics, 48. 513-548. http://dx.doi.org/10.1016/S0304-3932(01)00084-8

R. Chang, \& A. Velasco. (1999). Liquidity crises in emerging markets: theory and policy. In B. Bernanke and J. Rotemberg (Eds). NBER Macroeconomics Annual (pp. 11-58).

Raddatz, C. (2006). Liquidity needs and vulnerability to financial underdevelopment. Journal of Financial Economics, 80(3). 677-722.

Ramey, Garey, \& Valerie Ramey, (1995). Cross-Country Evidence on the Link Between Volatility and Growth. American Economic Review, 85(5). 1138-51.

Razin, \& Rose, A. (1994). Business-cycle volatility and openness: An exploratory cross-sectional analysis. In L. Leiderman \& A. Razin (Eds.). Capital Mobility: The Impact on Consumption, Investment, and Growth (pp. 48-76). Cambridge University Press.

Senay, O. (1998). The effects of goods and financial market integration on macroeconomic volatility. The Manchester School Supplement, 66. 39-61. http://dx.doi.org/10.1111/1467-9957.66.s.3 
Sutherland, A. (1996). Financial market integration and macroeconomic volatility. Scandinavian Journal of Economics, 98. 129-539. http://dx.doi.org/10.2307/3440882

T. Beck, M. Lundberg, \& G. (2001). Majnoni. Financial intermediary development and growth volatility.World Bank Policy Research Working Paper, 2707. World Bank.

\section{Notes}

Note 1. Periods are: 70-74, 75-79, 80-84, 85-89, 90-94, 95-99, 2000-2004 and 2005-2009.

Note 2. For simultaneous evolution of private credit and growth volatility looks at graphs in annexes.

Note 3. The results in table1 show that (i) test of second-order serial correlation justify the acceptance of the null hypothesis, and (ii) the Sargan test of over identification suggests that we cannot reject the hypothesis of the validity of instruments (prob $X^{2}>0.05$ ). It noted that we have instrumented the indicator of the financial development by its values lagged and time dummies variables to check the time effect.

Correlation matrix

\begin{tabular}{|c|c|c|c|c|c|c|c|c|}
\hline & FI & FD & E XCHANGE & GROWTHVOL & INFVOL & TRADEVOL & GOVVOL & $\mathrm{FI} * \mathrm{FD}$ \\
\hline FI & 1.0000 & & & & & & & \\
\hline FD & -0.0545 & 1.0000 & & & & & & \\
\hline EXCHANGE & 0.0425 & -0.2000 & 1.0000 & & & & & \\
\hline GROWTHVOL & 0.0669 & -0.1412 & 0.0981 & 1.0000 & & & & \\
\hline INFVOL & -0.0586 & -0.0767 & -0.0817 & 0.0777 & 1.0000 & & & \\
\hline TRADEVOL & 0.1141 & -0.0224 & 0.0854 & 0.0784 & 0.1120 & 1.0000 & & \\
\hline GOVVOL & -0.2466 & -0.3334 & 0.1684 & 0.1334 & 0.0376 & 0.0605 & 1.0000 & \\
\hline FI*FD & 0.5746 & -0.5496 & 0.2200 & 0.0828 & 0.0085 & 0.1330 & 0.1186 & 1.0000 \\
\hline
\end{tabular}

Table 1 . The volatility of the growth rate by decade: a comparative analysis between the various groups of countries

\begin{tabular}{lcccc} 
& \multicolumn{3}{c}{ Standard deviation of growth rate by group of countries in \% } \\
\cline { 2 - 5 } Groups & $1970-1979$ & $1980-1989$ & $1990-1999$ & $2000-2009$ \\
\hline Developped countries & 2.88 & 2.04 & 2.265 & 2.45 \\
Developing MFI (Note 4) & 3.7 & 4.88 & 4.54 & 3.65 \\
Developing LFI (Note 5) & 7.02 & 5.13 & 3.90 & 2.93 \\
\hline
\end{tabular}

*. MFI: More Financially integrated.

**. LFI: Less Financially Integrated.

Table 2. The evolution of financial development indicator from various groups

\begin{tabular}{lcccc} 
& \multicolumn{4}{c}{ Mean of private credit ratio to GDP in \% } \\
\cline { 2 - 5 } Groups & $1970-1979$ & $1980-1989$ & $1990-1999$ & $2000-2009$ \\
\hline All countries & 33 & 43 & 54 & 65 \\
Developped countries & 54 & 67 & 89 & 119 \\
Developing MFI & 28 & 40 & 51 & 54 \\
Developing LFI & 19 & 24 & 22 & 26 \\
\hline
\end{tabular}


Table 3. GMM-System Estimation of Growth volatility: full sample of 69 countries

\begin{tabular}{|c|c|c|c|c|}
\hline \multirow[t]{2}{*}{ Variables } & \multicolumn{4}{|c|}{ GMM-System } \\
\hline & (1) & (2) & (3) & (4) \\
\hline \multirow[t]{2}{*}{ Lagged dependant variable } & $0.420 * * *$ & $0.303 * * *$ & $0.341 * * *$ & $0.331 * * *$ \\
\hline & $(49.42)$ & $(50.36)$ & $(26.02)$ & (21.79) \\
\hline \multirow[t]{2}{*}{ Inflation volatility } & $0.00193 * * *$ & $0.00169^{* * *}$ & $0.00159^{* * *}$ & $0.00139 * * *$ \\
\hline & $(55.97)$ & $(54.60)$ & $(21.52)$ & $(25.50)$ \\
\hline \multirow[t]{2}{*}{ Exchange rate volatility } & $0.0230 * * *$ & $0.0390 * * *$ & $0.0312 * * *$ & $0.0371 * * *$ \\
\hline & $(14.85)$ & $(18.53)$ & $(16.11)$ & $(10.51)$ \\
\hline \multirow[t]{2}{*}{ Trade volatility } & $-0.166^{* * *}$ & $-0.117 * * *$ & $-0.105 * * *$ & $-0.0677 * * *$ \\
\hline & $(-20.04)$ & $(-14.62)$ & $(-9.413)$ & $(-2.914)$ \\
\hline \multirow[t]{2}{*}{ Government spending volatility } & $1.499 * * *$ & $1.198 * * *$ & $1.387 * * *$ & $1.579 * * *$ \\
\hline & $(59.66)$ & $(76.80)$ & $(70.10)$ & $(29.82)$ \\
\hline \multirow[t]{2}{*}{ Private credit } & & $-0.0936^{* * *}$ & $-0.0774 * * *$ & $-0.105 * * *$ \\
\hline & & $(-20.14)$ & $(-19.10)$ & $(-17.87)$ \\
\hline \multirow[t]{2}{*}{ Net private capital flows } & & & $0.0200 * * *$ & $0.0353 * * *$ \\
\hline & & & $(34.76)$ & $(21.36)$ \\
\hline \multirow[t]{3}{*}{ Credit*Capital flows } & & & & $-0.0609 * * *$ \\
\hline & & & & $(-9.324)$ \\
\hline & $(-37.24)$ & $(-58.15)$ & $(-36.77)$ & $(-25.31)$ \\
\hline \multirow[t]{2}{*}{ Constant } & $0.0370 * * *$ & $0.0850 * * *$ & $0.0817 * * *$ & $0.0841 * * *$ \\
\hline & $(77.65)$ & $(104.5)$ & $(58.21)$ & $(26.84)$ \\
\hline Observations & 483 & 483 & 483 & 483 \\
\hline Countries & 69 & 69 & 69 & 69 \\
\hline Serial correlation test $\mathrm{t}^{\mathrm{a}}$ ( $\mathrm{p}$-value) & 0.2343 & 0.2673 & 0.2646 & 0.3166 \\
\hline Sargan test $\mathrm{t}^{\mathrm{b}}$ (p-value) & 0.7709 & 0.9189 & 0.9995 & 0.9996 \\
\hline Threshold of Financial Development(\%GDP) & (Note 6) & & & 58 \\
\hline \multirow{2}{*}{\multicolumn{5}{|c|}{$\begin{array}{l}\text { Note: } \frac{\partial y}{\partial F I}=\beta_{3}+\beta_{4} D F^{*} \text { from regression (4). } \\
\text { T-stat in parentheses. }\end{array}$}} \\
\hline & & & & \\
\hline \multicolumn{5}{|c|}{ The regressions also includes dummy variables for the different time periods that are not reported. } \\
\hline \multicolumn{5}{|c|}{$* \mathrm{p}<0.1 ; * * \mathrm{p}<0.05 ; * * * \mathrm{p}<0.01$ indicate significance at the $10 \%, 5 \%$ and $1 \%$ level in the first-stage regression respectively. } \\
\hline \multirow{2}{*}{\multicolumn{5}{|c|}{$\begin{array}{l}\text { a. The null hypothesis is that the errors in the first-difference regression exhibit no second-order serial correlation. } \\
\text { b. The null hypothesis is that the instruments used are not correlated with the residuals. }\end{array}$}} \\
\hline & & & & \\
\hline
\end{tabular}


Table 4. GMM-System Estimation of Growth volatility : 20 developed countries

\begin{tabular}{|c|c|c|c|c|c|}
\hline \multirow[t]{2}{*}{ Variables } & \multicolumn{5}{|c|}{ GMM-System } \\
\hline & & $(1)$ & (2) & (3) & (4) \\
\hline \multirow[t]{2}{*}{ Lagged dependant variable } & $0.371 * * *$ & & $0.285 * * *$ & $0.292 * * *$ & $0.321 * * *$ \\
\hline & $(5.265)$ & & $(4.781)$ & $(4.726)$ & $(3.533)$ \\
\hline \multirow[t]{2}{*}{ Inflation volatility } & 0.622 & & 0.391 & 0.450 & 0.300 \\
\hline & $(1.631)$ & & $(1.039)$ & $(1.236)$ & $(0.638)$ \\
\hline \multirow[t]{2}{*}{ Trade volatility } & $-0.321 * * *$ & & $-0.289 * *$ & $-0.215^{*}$ & -0.175 \\
\hline & $(-3.558)$ & & $(-2.024)$ & $(-1.716)$ & $(-1.154)$ \\
\hline \multirow[t]{2}{*}{ Government spending volatility } & $3.250 * * *$ & & 1.167 & 0.741 & 1.519 \\
\hline & $(3.997)$ & & $(1.134)$ & $(0.634)$ & $(1.128)$ \\
\hline \multirow[t]{2}{*}{ Exchange rate volatility } & 0.0001 & & $0.0331 * * *$ & $0.0507 * * *$ & $0.0505 * *$ \\
\hline & $(0.0256)$ & & $(2.938)$ & $(2.658)$ & $(2.129)$ \\
\hline \multirow[t]{2}{*}{ Private credit } & & & $-0.0590 * * *$ & $-0.0642 * * *$ & $-0.0688 * * *$ \\
\hline & & & $(-11.81)$ & $(-9.364)$ & $(-6.841)$ \\
\hline \multirow[t]{2}{*}{ Net private capital flows } & & & & -0.00890 & 0.00343 \\
\hline & & & & $(-0.904)$ & $(0.127)$ \\
\hline \multirow[t]{2}{*}{ Credit*net capital flows } & & & & & -0.00551 \\
\hline & & & & & $(-0.285)$ \\
\hline \multirow[t]{2}{*}{ Constant } & $0.0338 * * *$ & & $0.0859 * * *$ & $0.0739 * * *$ & $0.0752 * * *$ \\
\hline & $(4.906)$ & & $(6.733)$ & $(4.719)$ & $(3.602)$ \\
\hline Observations & 133 & & 133 & 133 & 133 \\
\hline Countries & 19 & & 19 & 19 & 19 \\
\hline Serial correlation test ${ }^{\mathrm{a}}$ ( $\mathrm{p}$-value) & 0.0821 & & 0.0228 & 0.0187 & 0.0247 \\
\hline Sargan test ${ }^{\mathrm{b}}(\mathrm{p}$-value $)$ & 0.8507 & & 0.8630 & 0.8876 & 0.8950 \\
\hline
\end{tabular}

Table 5. System Estimation of Growth volatility: 50 developing countries

\begin{tabular}{|c|c|c|c|c|}
\hline \multirow[t]{2}{*}{ Variables } & \multicolumn{4}{|c|}{ Two Step GMM-System } \\
\hline & $(1)$ & (2) & (3) & $(4)$ \\
\hline \multirow[t]{2}{*}{ Lagged dependant variable } & $0.298 * * *$ & $0.255^{* * *}$ & $0.309^{* * *}$ & $0.293 * * *$ \\
\hline & $(12.72)$ & $(8.659)$ & $(6.830)$ & $(7.556)$ \\
\hline \multirow[t]{2}{*}{ Exchange rate volatility } & $0.0802 * * *$ & $0.0729 * * *$ & $0.0509^{* * *}$ & $0.0621 * * *$ \\
\hline & $(18.25)$ & $(10.18)$ & $(6.310)$ & $(5.985)$ \\
\hline \multirow[t]{2}{*}{ Inflation volatility } & $0.00285^{* * *}$ & $0.00256^{* * *}$ & $0.00246^{* * *}$ & $0.00235^{* * *}$ \\
\hline & $(8.134)$ & $(6.175)$ & $(6.321)$ & $(6.196)$ \\
\hline \multirow[t]{2}{*}{ Trade volatility } & $-0.151 * * *$ & $-0.120 * * *$ & $-0.0637^{*}$ & -0.0282 \\
\hline & $(-3.706)$ & $(-3.281)$ & $(-1.689)$ & $(-0.726)$ \\
\hline \multirow[t]{2}{*}{ Government spending volatility } & $1.433 * * *$ & $1.299 * * *$ & $1.490^{* * *}$ & $1.510^{* * *}$ \\
\hline & $(7.242)$ & $(5.083)$ & $(4.340)$ & $(4.965)$ \\
\hline \multirow[t]{2}{*}{ Private credit } & & $-0.0677 * * *$ & $-0.0659 * * *$ & $-0.0980^{* * *}$ \\
\hline & & $(-11.32)$ & $(-10.09)$ & $(-6.541)$ \\
\hline \multirow[t]{2}{*}{ Net private capital flows } & & & $0.0228 * * *$ & $0.0361 * * *$ \\
\hline & & & $(11.12)$ & $(9.683)$ \\
\hline \multirow[t]{2}{*}{ Credit*net capital flows } & & & & $-0.0725^{* * *}$ \\
\hline & & & & $(-5.420)$ \\
\hline \multirow[t]{2}{*}{ Constant } & $0.0144 * * *$ & $0.0459 * * *$ & $0.0551 * * *$ & $0.0540 * * *$ \\
\hline & $(4.530)$ & $(9.266)$ & $(10.05)$ & $(6.096)$ \\
\hline Observations & 350 & 350 & 350 & 350 \\
\hline Countries & 50 & 50 & 50 & 50 \\
\hline Serial correlation test ${ }^{\mathrm{a}}$ ( $\mathrm{p}$-value) & 0.3435 & 0.3272 & 0.2959 & 0.4147 \\
\hline Sargan test ${ }^{\mathrm{b}}$ (p-value) & 0.7537 & 0.7674 & 0.9994 & 0.9996 \\
\hline \multicolumn{4}{|c|}{ Threshold level of Financial Development (private credit in \%GDP) (Note 7) } & 50 \\
\hline
\end{tabular}

Note: $\frac{\partial y}{\partial F I}=\beta_{3}+\beta_{4} D F^{*}$ from regression (4). 
Table 6. GMM-System Estimation of Growth volatility: 32 LFIE countries.

\begin{tabular}{|c|c|c|c|c|}
\hline \multirow[t]{2}{*}{ Variables } & \multicolumn{4}{|c|}{ Two Step GMM-System } \\
\hline & (1) & (2) & (3) & (4) \\
\hline \multirow{2}{*}{ Lagged dependant variable } & $0.327 * * *$ & $0.291 * * *$ & $0.317 * * *$ & $0.304 * * *$ \\
\hline & $(8.391)$ & $(7.675)$ & $(7.766)$ & $(6.315)$ \\
\hline \multirow[t]{2}{*}{ Inflation volatility } & $0.00231 * * *$ & $0.00183^{* * *}$ & $0.00207 * * *$ & $0.00175^{* * *}$ \\
\hline & $(4.571)$ & $(3.250)$ & $(4.804)$ & $(2.820)$ \\
\hline \multirow[t]{2}{*}{ Trade volatility } & $-0.0854 * * *$ & $-0.0830 * *$ & -0.0550 & -0.0184 \\
\hline & $(-3.184)$ & $(-2.237)$ & $(-1.322)$ & $(-0.334)$ \\
\hline \multirow[t]{2}{*}{ Exchange rate volatility } & $0.0688^{* * *}$ & $0.0771 * * *$ & $0.0657 * * *$ & $0.0672 * * *$ \\
\hline & $(8.250)$ & $(7.238)$ & $(6.267)$ & $(5.718)$ \\
\hline \multirow[t]{2}{*}{ Government spending volatility } & $1.266^{* * *}$ & $1.078 * * *$ & $1.569^{* * *}$ & $1.531 * * *$ \\
\hline & $(8.982)$ & $(6.141)$ & $(9.712)$ & $(6.777)$ \\
\hline \multirow[t]{2}{*}{ Private credit } & & $-0.0914 * * *$ & $-0.0887^{* * *}$ & $-0.121 * * *$ \\
\hline & & $(-6.461)$ & $(-6.357)$ & $(-4.442)$ \\
\hline \multirow[t]{2}{*}{ Net private capital flows } & & & $0.0327 * * *$ & $0.0419^{* * *}$ \\
\hline & & & $(12.79)$ & $(9.581)$ \\
\hline \multirow[t]{2}{*}{ Credit*net capital flows } & & & & $-0.0728 * * *$ \\
\hline & & & & $(-2.834)$ \\
\hline \multirow[t]{2}{*}{ Constant } & $-0.0102 *$ & 0.00906 & $0.0181 * *$ & $0.0222 * *$ \\
\hline & $(-1.814)$ & $(1.329)$ & $(1.986)$ & $(2.135)$ \\
\hline Observations & 224 & 224 & 224 & 224 \\
\hline Countries & 32 & 32 & 32 & 32 \\
\hline Serial correlation test ${ }^{\mathrm{a}}(\mathrm{p}$-value $)$ & 0.2964 & 0.2753 & 0.4328 & 0.4794 \\
\hline Sargan test $\mathrm{t}^{\mathrm{b}}$ (p-value) & 0.2546 & 0.3302 & 0.2975 & 0.3050 \\
\hline \multicolumn{4}{|c|}{ Threshold level of Financial Development (private credit in \%GDP) (Note 8) } & 58 \\
\hline
\end{tabular}

Table 7. GMM-System Estimation of Growth volatility: 18 MFIE.

\begin{tabular}{|c|c|c|c|c|}
\hline \multirow[t]{2}{*}{ Variables } & \multicolumn{4}{|c|}{ Two Step GMM-System } \\
\hline & $(1)$ & (2) & (3) & (4) \\
\hline \multirow[t]{2}{*}{ Lagged dependant variable } & $0.569 * * *$ & $0.491 * * *$ & $0.405 * * *$ & $0.349 * * *$ \\
\hline & $(4.212)$ & $(5.858)$ & $(5.413)$ & $(3.791)$ \\
\hline \multirow[t]{2}{*}{ Inflation volatility } & 0.000412 & 0.000551 & 0.000580 & 0.000705 \\
\hline & $(0.824)$ & $(1.138)$ & $(0.958)$ & $(1.152)$ \\
\hline \multirow[t]{2}{*}{ Trade volatility } & 0.106 & -0.00177 & $0.160^{* *}$ & $0.184 * *$ \\
\hline & $(1.097)$ & $(-0.0204)$ & $(2.052)$ & $(2.293)$ \\
\hline \multirow[t]{2}{*}{ Exchange rate volatility } & $0.0426 * *$ & $0.0237^{*}$ & $0.0381 *$ & $0.0468 * *$ \\
\hline & $(2.406)$ & $(1.863)$ & $(1.692)$ & $(2.019)$ \\
\hline \multirow[t]{2}{*}{ Government spending volatility } & 3.541 & $2.061 * * *$ & $1.768 * * *$ & $1.308^{*}$ \\
\hline & $(1.393)$ & $(2.986)$ & $(2.705)$ & $(1.725)$ \\
\hline \multirow[t]{2}{*}{ Private credit } & & $-0.0603 * * *$ & $-0.0695 * * *$ & $-0.0947 * * *$ \\
\hline & & $(-4.498)$ & $(-5.255)$ & $(-4.927)$ \\
\hline \multirow[t]{2}{*}{ Net private capital flows } & & & $0.0402 * *$ & $0.0496^{* *}$ \\
\hline & & & $(2.225)$ & $(1.976)$ \\
\hline \multirow[t]{2}{*}{ Credit*net capital flows } & & & & -0.0309 \\
\hline & & & & $(-1.012)$ \\
\hline \multirow[t]{2}{*}{ Constant } & -0.00140 & $0.0578^{* * *}$ & $0.0601 * * *$ & $0.0729 * * *$ \\
\hline & $(-0.0802)$ & $(3.721)$ & $(3.382)$ & $(3.643)$ \\
\hline Observations & 126 & 126 & 126 & 126 \\
\hline Countries & 18 & 18 & 18 & 18 \\
\hline Serial correlation test ${ }^{\mathrm{a}}$ ( $\mathrm{p}$-value) & 0.9668 & 0.5159 & 0.8469 & 0.7017 \\
\hline Sargan test $\mathrm{t}^{\mathrm{b}}(\mathrm{p}$-value) & 0.9953 & 0.9805 & 0.9805 & 0.9907 \\
\hline
\end{tabular}


Countries list

\section{Countries}

Developed countries:

Austria, Belgium, France, Germany, Italy, Netherlands, the United Kingdom, Ireland, Spain, Finland, Denmark, Greece, Portugal, Sweden, Norway, the USA, Canada, Australia, New-Zélande, Japan.

Developing countries: MFIEs:

South Africa, Mexico, Argentina, Brazil, Chile, Colombia, Venezuela, Peru, Singapore, Thailand, Philippine, Indonesia, Malaysia, R. Korea, Egypt, Pakistan, Turkey, Morocco.

Developing countries: LFIEs:

Algeria, Bangladesh, Benin, Bolivia, Botswana, Burkina Faso, Burundi, Cameroon, Costa Rica, Côte d'Ivoire, Ecuador, El Salvador, Gabon, Ghana, Guatemala, Haiti, Honduras, Jamaica, Kenya, Maurice, Nicaragua, Niger, Nigeria, Panama, Papouasie-New-Guinia, Paraguay, Syria, Senegal, Sri Lanka, Togo, Tunisia, Uruguay.

Variables list

\begin{tabular}{|c|c|c|}
\hline Variables & Description & Source \\
\hline Growth Volatility & Standard deviation of GDP per capita in log per 5 years unit. & WDI \\
\hline $\begin{array}{l}\text { Inflation } \\
\text { Volatility }\end{array}$ & Standard deviation of inflation rate in per 5 years unit. & WDI \\
\hline Trade Volatility & Standard deviation of trade $(\mathrm{X}+\mathrm{M} / \mathrm{GDP})$ per 5 years unit. & WDI \\
\hline $\begin{array}{l}\text { Government } \\
\text { spending } \\
\text { Volatility }\end{array}$ & Standard deviation of government consumption share of GDP per 5 years unit. & WDI \\
\hline $\begin{array}{l}\text { Exchange rate } \\
\text { stability }\end{array}$ & $\begin{array}{l}\text { To measure exchange rate stability, Aizenman used annual standard deviations of the monthly } \\
\text { exchange rate between the home country and the base country are calculated and included in the } \\
\text { following formula to normalize the index between } 0 \text { and } 1 \text { : } \\
\qquad \text { ERS }=\frac{0.01}{0.01+\operatorname{sdev}(\Delta(\log (\text { exch rate })))}\end{array}$ & $\begin{array}{l}\text { Aizenman, J., M.D. } \\
\text { Chinn, and H. Ito. } 2008 .\end{array}$ \\
\hline $\begin{array}{l}\text { Private credit to } \\
\text { GDP }\end{array}$ & Private Credit by Deposit Money Banks and other Financial Institutions to GDP. & $\begin{array}{l}\text { WDI } \\
\text { Financial Structure } \\
\text { Database, Levine (2009). }\end{array}$ \\
\hline $\begin{array}{l}\text { Net private } \\
\text { capital flows }\end{array}$ & $\begin{array}{l}\text { NPCF }=\text { Total assets }- \text { Total liabilities where: } \\
\text { Total assets }=\text { FDI assets }+ \text { portfolio equity assets }+ \text { debt assets }+ \text { derivatives assets }+ \text { FX reserves } \\
\text { Total liabilities }=\text { FDI liabilities }+ \text { portfolio equity liabilities }+ \text { debt liabilities }+ \text { derivatives liabilities }\end{array}$ & $\begin{array}{l}\text { Lane, Philip R., and Gian } \\
\text { Maria Milesi-Ferretti } \\
\text { (2007). }\end{array}$ \\
\hline
\end{tabular}




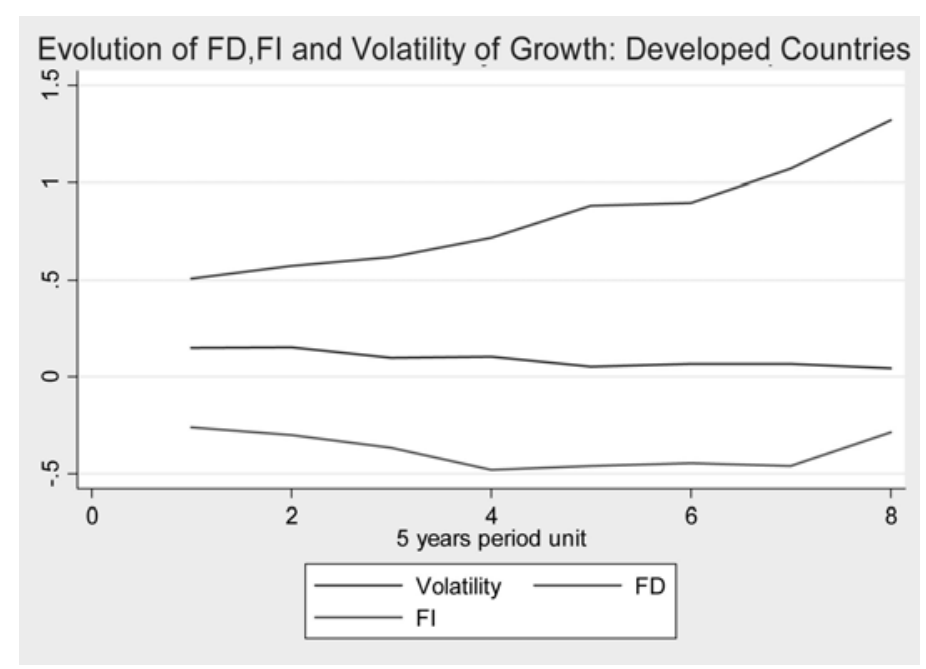

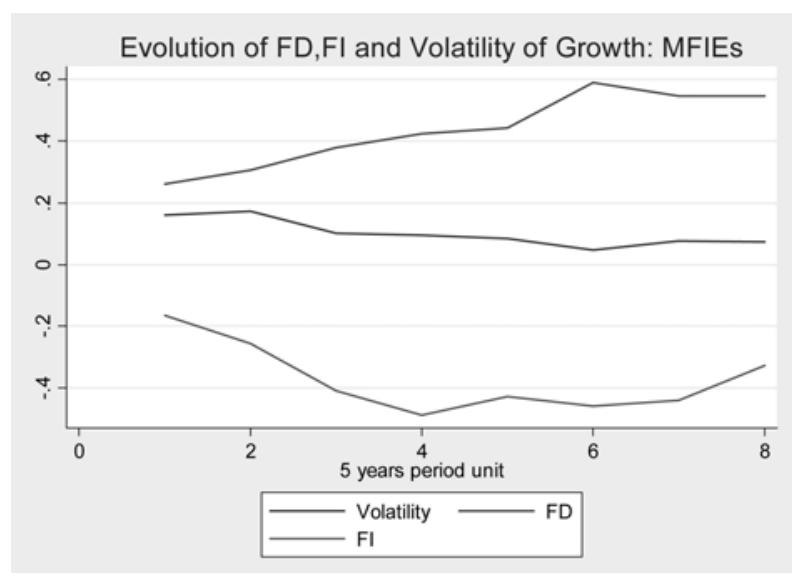

Evolution of FD,FI and Volatility of Growth: Full Sample

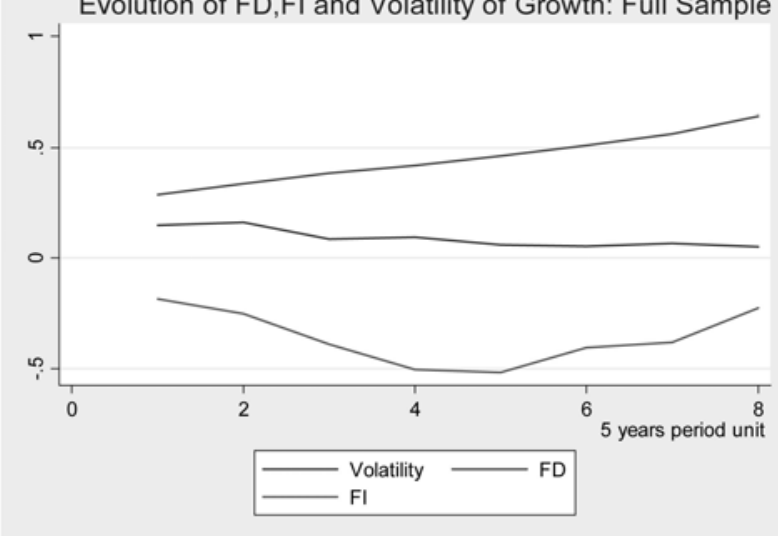

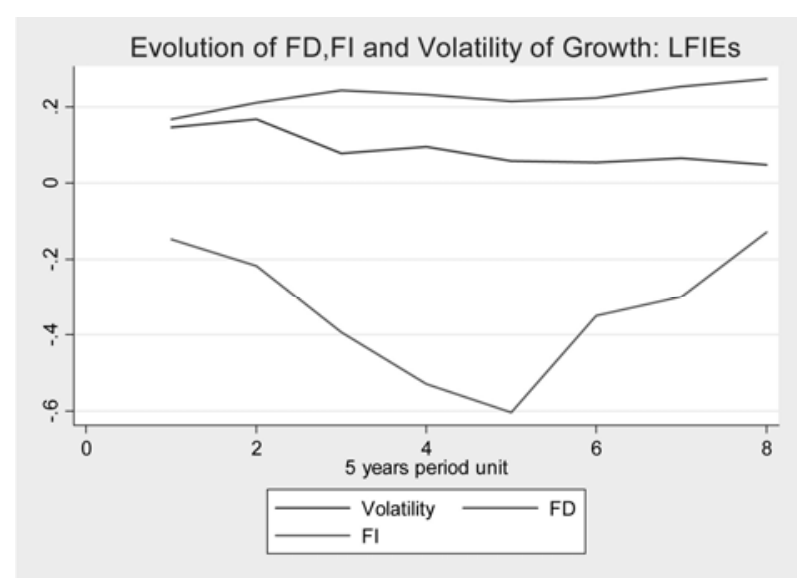

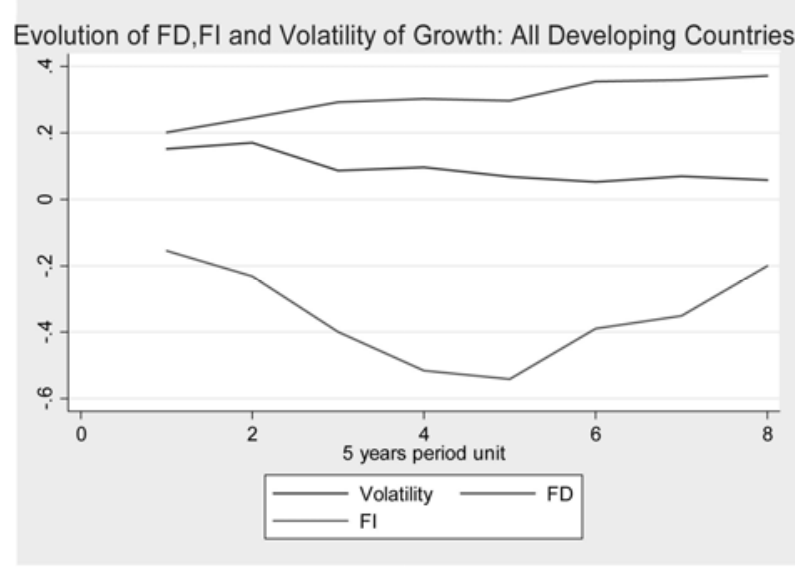

Figure 1. 